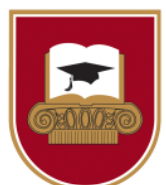

Vadyba

Journal of Management

2020, № 1 (36)

ISSN 1648-7974

\title{
ASSESSMENT OF CAUSES FOR STUDENT MOBILITY UNDER ERASMUS+ PROGRAM
}

\author{
Samanta Štraupaitè \\ Lithuania Business University of Applied Sciences
}

\begin{abstract}
Studying abroad is an enriching learning experience through which students can meet new people and become actively involved in a new environment (Yang et al. 2011). Cultural distance between the host country and the home country can be a challenge for students, but this process can easily be facilitated when the language of the host country is communicated (Chirkov et al. 2007). In their study, V. Chirkov et al. (2007) found that little attention was paid to promoting students' motivation to study abroad and developing their cultural awareness, which could have helped them gain experience abroad. N. Rinehart (2002) explains that in their academic experience abroad, students are not only introduced to the host university's academic culture, but also face new social norms and the host culture's lifestyle. Thus, students are forced to step out of the comfort zone and adapt their abilities to different socio-cultural contexts in order to expand their abilities for intercultural communication and intercultural understanding (Singh 2013; Yang et al. 2011). It is important to know the strengths and weaknesses of all Higher Education institutions and their International Relations Offices - to know the students' reasons when choosing their city or institution, if they want to work effectively and receive the highest numbers of Erasmus+ students. This article analyses causes for student mobility under Erasmus+ program at one of Klaipeda Higher Education Institution. The article presents the reasons and motives of all incoming students that arrived by Erasmus+ exchange program in the 2018 / 2019 and 2019 spring semester in one of Klaipeda Higher Education Institution. Also we analyse students' interests and expectations before studying and motives to choose Lithuania and Klaipeda as a city for Erasmus+ studies. In our study we used qualitative methods - interviews, statistical analyses, comparative analyses and literature review. Our subjects were students coming to one of Klaipeda Higher Education Institution under the Erasmus+ program. The relevance on the article that we noticed changes in the number of incoming Erasmus+ students in the spring semester of the 2018-2019 academic year to one Klaipeda Higher Education Institution. Since the incoming Erasmus+ students number is one of the important indicators of the Higher Education Institution's activity, it is important to clarify the factors and expectations of incoming Erasmus + students. The research reveals the causes for student mobility under Erasmus+ program.
\end{abstract}

KEY WORDS: Erasmus+ mobility; studies; internationalization; expectations; motives.

\section{Introduction}

The relevance of the article is that student mobility has been under way since 1987, when the Erasmus program was established as part of the European Union's Lifelong Learning Program. It encourages Europeans to learn and develop new skills throughout their lives. The Erasmus + program is related to higher education and its overall objective is to create a European Higher Education Area by promoting innovation in Europe (European Commission Erasmus+ program guide 2019).

The New Louvain Forum was established to develop access to lifelong learning and equal learning opportunities, as well as to promote international exchanges in higher education. At the Second Bologna Policy Forum in Vienna, the main topics of discussion were the need for higher education systems and higher education institutions themselves to respond to growing needs and expectations, to strike a balance between cooperation and competition in the international arena; The countries involved in the Bologna Process need to liaise, exchange information and act together, including in the run-up to the next Bologna Policy Forum, and support student dialogue worldwide (EAME documents 2012). In order to promote learning, an Operational Program on Investments of the European Union Funds 2014-2020 has been prepared, which, under Priority 9 "Public
Education and Increasing Human Resources Potential”, includes investments in education, vocational training, improvement of education and training infrastructure to provide skills and Lifelong Learning Opportunity (European Union Funds Investment Action Program 2014-2020, 2018).

Internationalization is becoming an increasingly important topic these days, with the European Commission providing new projects and programs to promote the internationalization of citizens, organizations and universities. It is important to know the strengths and weaknesses of all Higher Education institutions and their International Relations Offices to know the students' reasons when choosing their city or institution if they want to work effectively and receive the highest numbers of Erasmus+ students. Erasmus+ students are one of the indicators of the internationality of Higher Education Institutions in Europe. Due to the fact that the numbers of Erasmus+ students is important, there was a noticeable lack of research in one of Klaipeda Higher Education Institution. There was an equal decrease in the number of outgoing students and an increase in the number of incoming students via the Erasmus+ program. The lack of research and information prompted us to conduct research on this topic to improve the International Relations Office goals of one of Klaipeda Higher Education Institutions. In order to ensure the quality of student mobility and increase incoming 
flows, it is important to find out the expectations of students when choosing the Erasmus+ program and their motivation to choose a certain city and institution for their mobility.

During the research there was noticed that there were significant changes in the number of Erasmus+ students coming to the one of Klaipeda higher education institutions in the spring semester of the 2018-2019 academic year. As the number of incoming Erasmus+ students is one of the important indicators of the performance of a higher education institution, the relevance of the article is determined by the need to find out the factors and expectations of incoming Erasmus+ students.

The scientific novelty of this article is that internationalization is becoming an increasingly important topic these days, with the European Commission providing new projects and programs to promote the internationalization of organizations and universities. There are some researchers that analyses the Erasmus+ students motives in some countries in Europe: Romania - F. Salajan and S. Chiper (2012), Finland - V. Andreotti (2012) and etc. In Lithuania the topic of internationalization is relatively new and there was no study ever conducted about the reasons and motives of Erasmus+ students in one of Klaipeda Higher education institution and this research is the first one.

The aim is to investigate the expectations of incoming Erasmus+ students and the factors that motivate their choice for Klaipeda and the particular Higher Education institution.

The object of this research consists from all incoming Erasmus+ students in one of Klaipeda Higher Education Institutions who arrived in 2018-2019 and in 2019, in the spring semester - in general there were 51 Erasmus+ students.

The tasks of the research is to identify Erasmus+ students expectations before entering the Erasmus+ exchange program and their motives, by country and city.

Research methods: qualitative research methods such as interviews, questionnaires, statistical data analysis, comparative analysis, literature review and document analysis methods.

\section{Internationalization as a part of Erasmus+ mobility}

The concept of mobility is used in many fields such as anthropology, geography, science and technology studies, tourism and transport studies. For example, scientists M. Sheller et al. (2006), Hannam et al. (2006), argue that social science disregards the systematic mobility of people for work, leisure, politics and other purposes. It also states that studies in the social sciences are static. In this context, they emphasize that the concept of mobility is also trying to provide a new perspective on static social sciences.

Professor V. de Oliveira Andreotti of the University of Oulu, along with colleagues, conducted a study on the globalization of students in Finland. Higher education students interviewed before and after the mobility period were studied. The results of the study revealed that students after the mobility period acknowledged that international exchanges had, in many cases, made a difference, from self-confidence to changing attitudes to the world. It was also noticed that students' abilities and personality traits were strengthened during the mobility, and students got to know themselves better. The greatest impact of the mobility was on increased self-esteem and students' feelings of improved and deepened knowledge (Andreotti et al. 2012).

A study by the Finnish National Agency for Studies on Student Globalization highlighted the importance of getting to know upcoming challenges, discussing a new culture, and setting goals before leaving. Discussing these issues with students can help them adapt to the new environment and get into the rhythm of that country. The results of the Global Minded-ness survey show that graduate students have a slightly more flexible attitude towards international differences than students who remain in their higher education institution. From an equality point of view, it would be crucial for higher education institutions to enable students to adapt to as diverse a group as possible and to encourage each other to benefit from international exchanges (Finnish National Agency for Education 2017). A tolerant approach that comes from international mobilities hugely influences personality, therefore intercultural communication means that one or another cultural attribute of an individual or group is one of many diversity and cannot be absolutized and emphasized (Mauricienè 2013).

Changes in the number of Erasmus+ students coming to Lithuania

Erasmus is a program for higher education, a mobile student seeking European study standards. This program has been implemented in Europe since 1987, and Lithuania joined it in 1999 (Regulation of the European Parliament and of the Council, 2013). From the accession period to the present day, the interest of incoming students in Lithuania is constantly on the rise. The number of students arriving not only for studies but also for practice is increasing.

Before assessing the number of incoming international students in one of Klaipeda Higher Education institutions, it is important to see how this number has changed throughout Lithuania. In the academic year 2015-2016. 2,164 students came to Lithuania for partial Erasmus + studies and 387 students for internships. In 2016-2017 study year 2,408 students came for partial studies and 588 students for internships. According to the latest data, 2017-2018 study year 2,487 students came to study and 712 students came as interns (Table 1) (Education Exchanges Support Foundation Report 2018). Thus, we can see that there is a growing interest of foreign students in Lithuania and studying there. 
Table 1. Students coming to Lithuania under the Erasmus + program 2015-2018 m.

\begin{tabular}{|c|l|l|l|}
\hline Period & $\begin{array}{l}\text { Type of the } \\
\text { mobility }\end{array}$ & Numbers & \% \\
\hline \multirow{2}{*}{$\begin{array}{c}2015- \\
2016\end{array}$} & Studies & 2164 & 85 \\
\cline { 2 - 4 } & Internship & 387 & 15 \\
\cline { 2 - 4 } & Total & 2551 & 100 \\
\hline \multirow{2}{*}{$2016-$} & Studies & 2408 & 80 \\
\cline { 2 - 4 } 2017 & Internship & 588 & 20 \\
\cline { 2 - 4 } & Total & 2996 & 100 \\
\hline \multirow{2}{2}{$2017-$} & Studies & 2487 & 78 \\
\cline { 2 - 4 } 2018 & Internship & 712 & 22 \\
\cline { 2 - 4 } & Total & 3199 & 100 \\
\hline
\end{tabular}

It can be assumed that students are very keen on getting to know Europe and therefore choose to study in the European Union. Western countries such as France, Italy, Spain and Germany have the largest populations in the EU so it is natural that the number of students enrolled under Erasmus+ is high (Eurostat data base 2019). Since it is known that in Lithuania the number of students are growing, it might be possible to admit the facts that in one of Klaipeda Higher Education Institutions, the number is also growing.

Erasmus+ students coming to Klaipeda Higher Education Institution

Lithuania isknown to receive higher numbers of Erasmus+ students each year. There is a slightly noticeable growing number at one of Klaipeda Higher Education institutions, but the numbers were not too high - around 10 students per semester. Therefore it was important for International Relations offices to know the reasons and expectations of Erasmus+ students so as to increase their numbers in the future.
Since all students' opinion was important, we decided to use qualitative research methods - interviews with all Erasmus+ students who arrived in 2018-2019 and in 2019 - the spring semester. On the whole there were 51 Erasmus+ students.

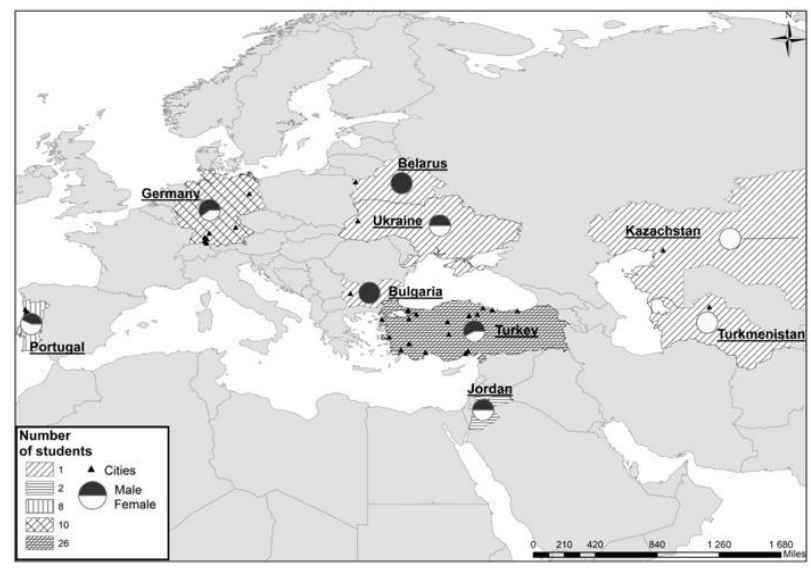

Fig. 1. Distribution of students entering one of Klaipeda Higher Education Institution by country 2018-2019

In the 3 semesters (2018-2019 academic year and in 2019 spring semester) 51 student came to one of Klaipeda Higher Education Institutions, (19 females and 32 males). Most of the incoming students (26) were from Turkey, 8 students came from Portugal, 10 students from Germany, 2 students from Jordan, one student from Ukraine, one from Turkmenistan, one from Kazakhstan and one from Bulgaria (Figure 1). Thus, we can see that students arrive from different countries and distance is not a limit for the mobility. Usually it becomes more usual to travel just to find different types of personalities and learn new skills such as leadership or other (Hanson 2010).

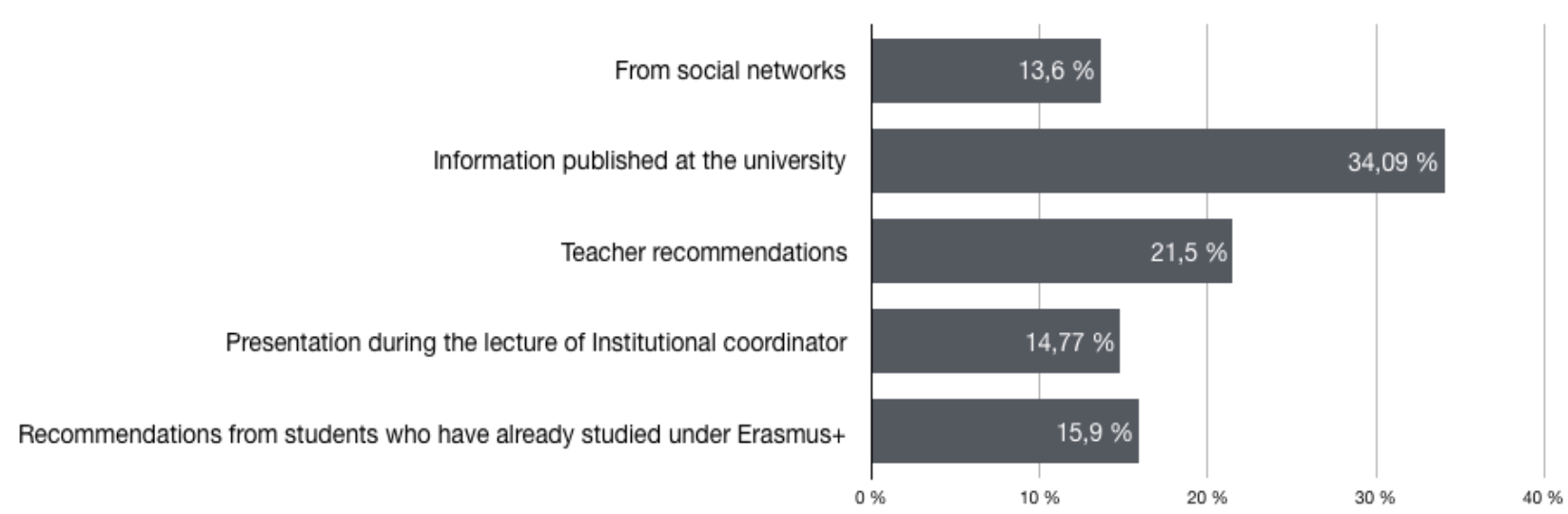

Fig. 2. Information sources for incoming students about mobility opportunities, $\%$

During the study, incoming students were asked where they learned about the possibilities of the Erasmus+ program (Figure 2). Most students accessed this information published at the university (34.09\%). Equally important are the recommendation of the head of department/lecturer $(21.5 \%)$, recommendations from students who have already studied under the Erasmus+ program $(15.9 \%)$, as well as the presentation of the Erasmus coordinator during lectures $(14.77 \%)$, and information on social networks $(13.6 \%)$. From these answers we can see that some incoming students are self-sufficient and able to find useful information for 
themselves, but for the other students live contact is important and they need help or encouragement from lecturers or colleagues. Intercultural communication can be one of the ways to get to know, understand, exchange knowledge and experience. Erasmus+ mobility is the basis of intercultural communication that is used between different cultures and is often understood as international communication (Baršauskienè et al. 2005).

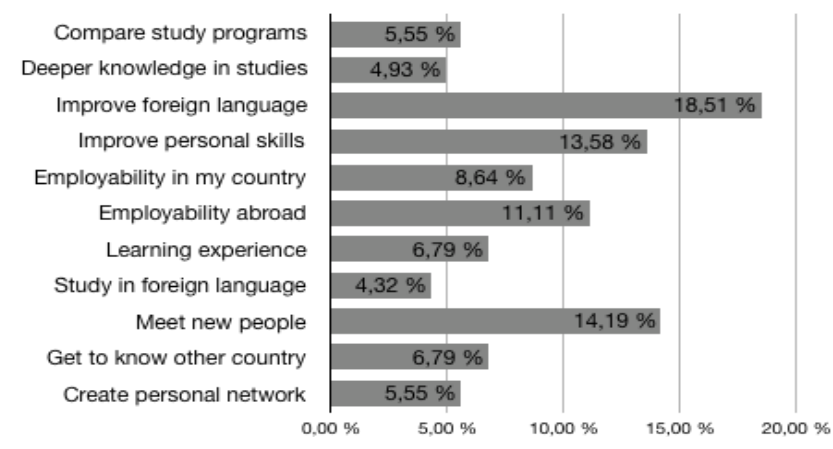

Fig. 3. Incoming students' motivations for Erasmus + study, $\%$
In order to find out the expectations of students, the incoming students were asked at the beginning of the semester what motivated them to study under Erasmus+ (Figure 3). Most students (18.51\%) want to improve their foreign language, some hope to meet new people (14.19\%), students expect to improve their skills such as adapting to the environment and problem solving, and meet new people $(13.58 \%)$. The survey noted the interesting fact that for students what matters to increase future employment opportunities at home $(8.64 \%)$ and abroad (11.11\%). So it may be assumed that incoming students purposefully think about their future, laying the groundwork for it and therefore even by personality type, students are committed to the Erasmus+ exchange program. During the mobility students improve their international thinking by understanding that by working together, individuals can improve their knowledge of the world by developing a shared understanding of local/global realities and taking appropriate action as part of their responsibilities (Harwood et al. 2012; Taylor 2015).

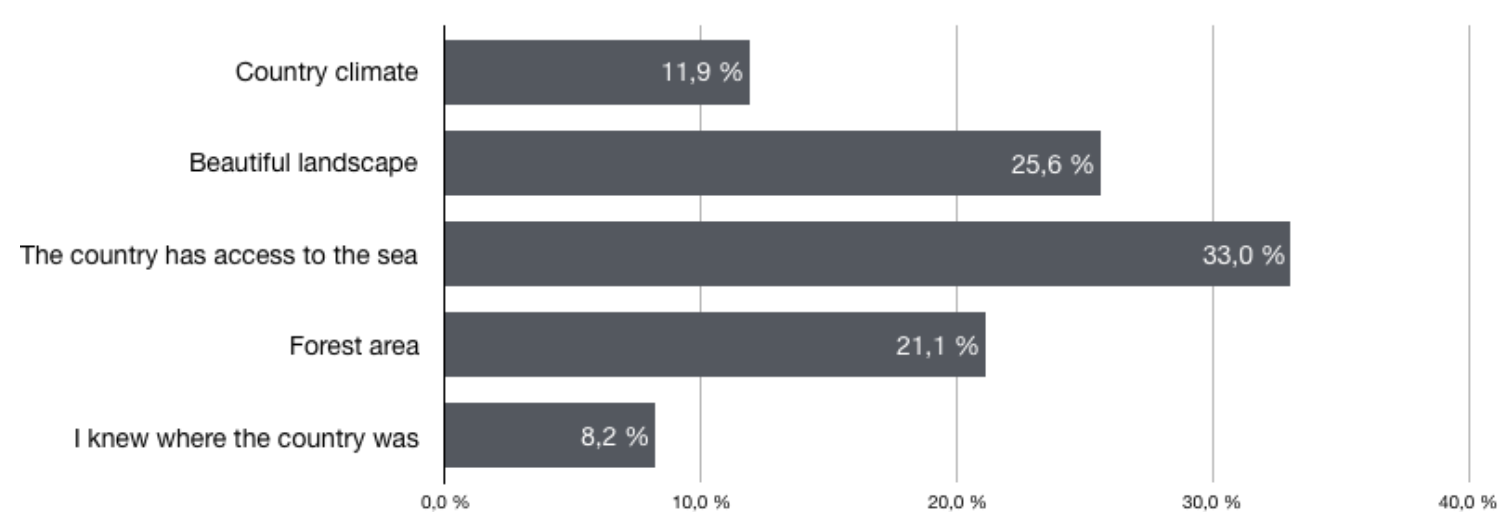

Fig. 4. Incoming students' natural geographical motives (factors) influencing country choice, $\%$

After finding out that incoming students are open minded and willing to improve their personal skills, it is still important to determine what factors influenced Lithuania's choice for Erasmus+ study mobility (Figure 4). During the interviews students identified the main factors that determined their choice. First of all, geographic factors are important for students: the country has access to the sea (33\%), landscape $(25.6 \%)$. To the students it is also important that the country has a forest area $(21.1 \%)$. The climate of the country matters $(11.9 \%)$ and it is important to the students that they already knew where the country was located $(8.2 \%)$. This shows that students collect information about the country before the mobility.
During the mobility students become open minded they improved by developing openness to different cultural experiences and the ability to collaborate with cultural groups, which are a prerequisite for global citizenship. Facing a different reality abroad can take the form of rejection and can lead to a person's openness and communication, which depends on intercultural adaptation and preparation. M. Barrett et al. (2011) noticed that prejudice is only diminished by constant intercultural contact, which involves groups of people having the same status in pursuit of common goals. People outside the international environment may be satisfied with their experience and personal level of thinking about cultural diversity (Cohen et al. 2015; Westrick 2005; Urry 2000). 


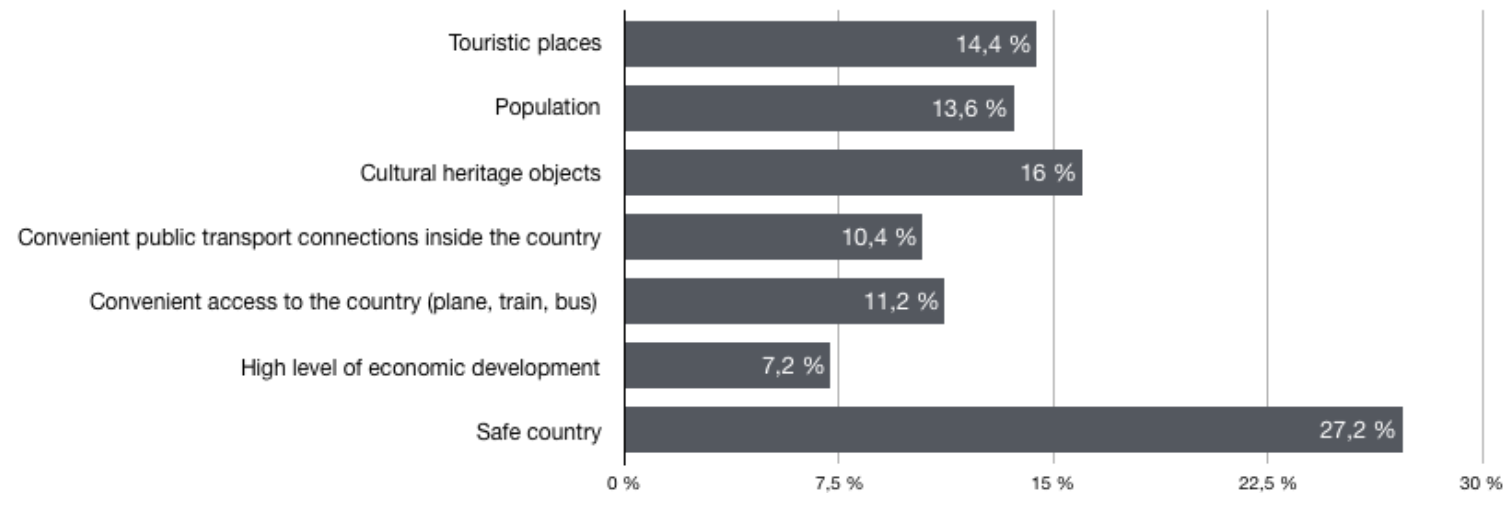

Fig. 5. Incoming students' social economical motives (factors) influencing country choice, $\%$

For students social factors are also relevant: national security $(27.2 \%)$, cultural heritage objects $(16 \%)$, touristic places $(14.4 \%)$, population $(13.6 \%)$ and convenient access within the country (11.2\%), convenient public transport inside the country (10.4\%), and a high level of economic development $(7.2 \%)$. These results indicate that students intend to travel within and outside the country during their studies.

A person is aware of cultural differences and learns more about himself. New experiences allow students to absorb new values, symbols, and norms that are acceptable to society. Constructing a new stage of life gives the individual self-satisfaction and opens up new opportunities for improvement (Phillips 2011).

Table 3. Number of incoming students according to the reasons for the choice of the city (number of respondents in brackets)

\begin{tabular}{|l|l|}
\hline Category & $\begin{array}{l}\text { Number of } \\
\text { students }\end{array}$ \\
\hline ...because of the sea (port)... & 5 \\
\hline ... because of the location... & 18 \\
\hline $\begin{array}{l}\text {.. recommendations of friends } \\
\text { (coordinator)... }\end{array}$ & 12 \\
\hline$\ldots$ because of the culture... & 9 \\
\hline ... because it's safe city.. & 7 \\
\hline
\end{tabular}

After finding out the reasons for choosing the country, students were asked an open question about why they chose Klaipeda. Most repetitive responses were categorized (Table 3). The most frequent students' answers were that they chose Klaipeda because of the climate (18 students), Klaipeda was recommended by their friends (12 students), they chose it because of its culture ( 9 students), because it is a safe city (7 students) or because of the port (5 students). From these answers we can assume that incoming students have taken into account the natural and geographical conditions, the credibility and the recommendations of the institution when choosing the institution of higher education.
Table 4. Number of incoming students according to the reasons for the choice of the institution (number of respondents in brackets)

\begin{tabular}{|l|l|}
\hline Category & $\begin{array}{l}\text { Number of } \\
\text { students }\end{array}$ \\
\hline $\begin{array}{l}\text {...coordinator recommended } \\
\text { because of good hospitality... }\end{array}$ & 12 \\
\hline $\begin{array}{l}\text {.. good feedback from other } \\
\text { Erasmus+ students... }\end{array}$ & 9 \\
\hline $\begin{array}{l}\text {... study subjects fits my study } \\
\text { area... }\end{array}$ & 5 \\
\hline $\begin{array}{l}\text {.. I saw amazing advertisement } \\
\text { of this university... }\end{array}$ & 15 \\
\hline $\begin{array}{l}\text {... the university is at very good } \\
\text { location... }\end{array}$ & 10 \\
\hline
\end{tabular}

Students were asked about the reasons why they chose that particular institution for their Erasmus+ studies and the answers were: students saw an advertisement of the university (15 students), the coordinator in their home university recommended it because of good hospitality (12 students), the university has a very good location (10 students), there was good feedback from other Erasmus+ students (9 students) and the study subjects best corresponded to their study area (5 students). From the students' answers one can see that advertisements influence their choices, as well as the home institution coordinator's recommendations. It might be worth investing in the advertisements in the future to increase the number of incoming Erasmus+ students.

Therefore incoming students are increasingly interested in Erasmus+ studies. They are active and interested in the processes taking place in the European Union. Through their Erasmus+ program, students hope to improve their skills, meet new people and increase their future employability. For students who choose Lithuania for Erasmus+ studies what matters is access to the sea, and national security. When choosing a city in the country, students take into consideration the climate and geographical location. Studying abroad raises not only academic but also spiritual problems (Pruskus 2012). Students studying abroad often see that the new culture is quite different from what they had 
hoped for, and there are frequent frustrations. Llurda et al. (2016) singled out "alien student syndrome" as a consequence of cultural shock characterized by a feeling of obscurity, passivity, physical grievance, separation, and disorder.

\section{Conclusions}

The research revealed that incoming students from the European Union countries are increasingly interested in the possibilities of the Erasmus+ exchange program in Lithuania, and there is a growing interest of non-EU students. This leads to a methodology applied in Eastern European universities to encourage their students to lay the foundations for their future, to gain knowledge abroad, so that upon returning to their home country, a person could have more opportunities for employment or postgraduate studies.

Incoming students are active, and their expectations are not only to improve their foreign language skills (18.51\%) and to meet new people (14.19\%) during their mobility, but also to increase future employment opportunities in their own country $(8.64 \%)$ or abroad $(11.11 \%)$. We may assume that incoming students are purposefully thinking about their future. Therefore, the Erasmus+ program offers students the opportunity to take on an international and life-long experience.

The interest of incoming students in Lithuania is growing and their motivation to choose this country are: geographical factors - the country has an access to the sea $(33 \%)$ or the country's landscape $(25.6 \%)$. Social factors such as the national security of the country $(27.2 \%)$ or cultural heritage objects $(16 \%)$ are also important for the incoming students.

Incoming Erasmus+ students choose Klaipeda as a city because of climate (18 students) and because Klaipeda was recommended by friends (12 students).

When students choose the institution for their Erasmus+ studies they mostly pay attention to the advertisement of the university (15 students) and the recommendations of their home university coordinator (12 students).

To sum up, based on this research, the recommendation is to host students in the best way possible, so that they could give the best feedback. Also, advertisements at all Higher Education institutions are very important. During the mobility students should experience local culture. students improve their communication skills, increase their cultural adaptation and develop a heightened sense of identity.

\section{References}

Andreotti V. (2012). Global Education in the '21st Century': two different perspectives on the 'post-' of postmodernism. International Journal of Development Education and Global Learning. Volume 2, No. 2. p. 522

Barrett, M., Flood, C., Eade, J. (2011). Nationalism, Ethnicity, Citizenship: Multidisciplinary Perspectives An Introduction. In Barrett, M., Flood, C. and Eade, J. (Eds.) (2011) Nationalism, Ethnicity, Citizenship: Multidisciplinary Perspectives Newcastle-upon-Tyne: Cambridge Scholars Publishing.
Baršauskienè, V., Janulavičiūtè-Ivaškevičienė, B. (2005). Komunikacija: teorija ir praktika. Kaunas: Technologija

Chirkov, V., Vansteenkiste, RT., Lynch, M. (2007). The role of self-determined motivation and goals for study abroad in the adaptation of international students. International Journal of Intercultural Relations, 31(2), p. 199-222.

Cohen, E., Cohen, S. A. (2015). A mobilities approach to tourism from emerging world regions. Current Issues in Tourism, 18(1), p. 11-43.

EAME documents (2012). Key documents of the Bologna Process were adopted at the Bucharest Ministerial Conference. p. 37. [Revised $2019 \quad 12 \quad$ 10], https://www.smm.lt/uploads/documents/Papildomas $\% 20$ meniu2/Bolonijos_procesas/Bolonijos\%20proceso\%20do kumentai_2013.pdf

European Commission Erasmus+ program guide (2019). Volume 2, p. 354. [Revised $2019 \quad 12$ 11], https://ec.europa.eu/programmes/erasmusplus/sites/erasmusplus2/files/erasmus-plus-programmeguide-2019_lt.pdf

European Union structural and Investment funds 2014-2020: Official texts and commentaries (2015). P. 418. [Revised 201912 15], https://ec.europa.eu/regional_policy/sources/docgener/gui des/blue_book/blueguide_en.pdf

Eurostat data base (2019). [Revised $2019 \quad 12$ 11], http://appsso.eurostat.ec.europa.eu/nui/show.do?dataset= demo_pjan\&lang=en

Finnish National Agency for education (2017), Students heading abroad are flexible and understand different perspectives.

Hannam, K., Sheller, M., Urry, J. (2006). Editorial: Mobilities, immobilities and moorings. Mobilities, 1(1), p. 1-22.

Hanson, L. (2010). Global citizenship, global health, and the internationalization of curriculum: A study of transformative potential. Journal of Studies in International Education (14), p. 70-88.

Harwood, R., \& Bailey, K. (2012). Defining and evaluating international mindedness in a school context. International Schools Journal. XXXI (2), p. 77-86.

Yang, M., Webster, B.J., Prosser, M.T. (2011). Travelling a thousand miles: Hong Kong Chinese students' study abroad experience. International Journal of Intercultural Relations, 35(1), p. 69-78.

Llurda E., Gallego-Balsa L., Barahona C., Martin-Rubio X. (2016). Erasmus students mobility and the construction of European citizenship. The Language Learning Journal. No. 2016, p. 28-39.

Mauricienė, I. (2013). Tarpkultūrinių kompetencijų raiška aukštojo mokslo institucijoje. Vadyba Journal of Management, Vol. 22, No. 1, 2013, p. 31-36.

Phillips, E. (2011). International mindedness and intercultural awareness in the MYP: A relationship reviewed. In M. Hayden \& J. Thompson (Eds.). Taking the MYP Forward. Woodbridge, UK: John Catt Publication, p. 3345.

Pruskus,V. (2012). Tarpkultūrinè komunikacija ir vadyba. Vilnius: Vilniaus pedagoginis universitetas

Regulation of the European Parliament and of the Council (2013). No. 1304/2013, December 17, p. 17. [Revised 201912 11], https://eur-lex.europa.eu/legalcontent/EN/TXT/PDF/?uri=CELEX:32013R1304\&from $=\mathrm{EN}$

Rinehart, N. (2002). Utilitarian or idealist? Frameworks for assessing the study abroad experience. In Grünzweig W and Rinehart N (Eds.), Rockin' in red square: Critical approaches to international education in the age of cyberculture p. $75-84$. 
Salajan, F., Chiper, S. (2012) Value and benefits of European student mobility for Romanian students: experiences and perspectives of participants in the ERASMUS programme, European Journal of Higher Education, 2:4, 403-422, DOI: 10.1080/21568235.2012.737999

Singh, M., Qi, J. (2013). Disseminating Tibetan knowledge: The intellectual enfranchisement of Indigenous peoples, Charlotte, NC: Information Age Publishing.

Švietimo mainų paramos fondo veiklos apžvalga (2018). p. 32. [Revised 201912 15], https://www.smpf.lt/wpcontent/uploads/2019/05/2018-metine-ataskaita-sunuorodomis.pdf
Taylor, S. (2015). Globally-minded students: Defining, measuring and developing intercultural sensitivity. International and Global Issues for Research. No. 2015/3 June. p. 1-32.

Urry, J. (2000). Sociology Beyond Societies: Mobilities for The Twenty-First Century, London \& New York: Routledge.

Westrick, J. M. (2005). Phenomenology and Meaning Making: Student Voices and Understandings of Cultural Difference. Journal of Studies in International Education, 9 (2), p. 105-20.

Samanta Štraupaitė, Master of Human Geography and GIS application, Head of International Relations and projects department and assistant at Lithuania Business University of Applied Sciences. Research area - intercultural difference and identity. The author has already published 2 articles about youth and Erasmus+ students. Address: Turgaus str. 21, Klaipéda, Lithuania, phone: +370 46314 320, E-mail: samanta.straupaite@gmail.com 
